Retraction

\title{
Retracted: Operational Risk Assessment for International Transport Corridor: A Case Study of China-Pakistan Economic Corridor
}

\author{
Discrete Dynamics in Nature and Society
}

Received 16 August 2020; Accepted 16 August 2020; Published 30 September 2020

Copyright () 2020 Discrete Dynamics in Nature and Society. This is an open access article distributed under the Creative Commons Attribution License, which permits unrestricted use, distribution, and reproduction in any medium, provided the original work is properly cited.

Discrete Dynamics in Nature and Society has retracted the article titled "Operational Risk Assessment for International Transport Corridor: A Case Study of China-Pakistan Economic Corridor" [1]. A high level of overlap was identified with a thesis by Jing Xia, who graduated from the Chongqing Academy of Agricultural Sciences, Chongqing Jiaotong University, and participated in the design and conception of the research, questionnaire design, and data collection. The authors did not have the permission to publish, and the article is therefore being retracted with the agreement of all the authors and their institution.

\section{References}

[1] Y. Lei, C. Huang, and Y. Wu, “Operational Risk Assessment for International Transport Corridor: A Case Study of ChinaPakistan Economic Corridor," Discrete Dynamics in Nature and Society, vol. 2019, Article ID 5730746, 7 pages, 2019. 